\title{
What competences make translation teachers happy?
}

\author{
Vadim V. Sdobnikov ${ }^{1 *}$ \\ ${ }^{1}$ Linguistics University of Nizhny Novgorod, Higher School of Translation and Interpreting, \\ Department of Translation Theory and Practice, Nizhny Novgorod, Russia
}

\begin{abstract}
The study is conditioned by the lack of systematic training for translation teachers both in Russia and in foreign countries. To improve the quality of preparing translators, it is necessary to determine the basic principles of training those who teach them, i.e. translation teachers. The study aims at describing a set of competences that a translation teacher should have. To attain this end, the authors used the following methods: a literature overview on the training of translation teachers; the analysis of prominent works containing theoretical provisions that contribute to the development of basic principles for training translation teachers; a questionnaire survey of translation teachers in the Russian universities. The survey has demonstrated that about half of translation teachers have a special degree in translation, while the other half have only a philological degree. Teachers of both categories have not mastered translation didactics. Philology teachers often do not have sufficient translation experience and have a poor command of translation theory. Thus, modern translation teachers do not have a special set of competences that would allow them to effectively train future translators. As a result, a model of the competences of a translation teacher was proposed, including three blocks: professional translation competences, general and special didactic competences. Thus, the scientific novelty of the research lies in the formulation of strict requirements for the training of translation teachers.
\end{abstract}

Keywords: translation teacher, translation theory, translation competence, common didactic competence, specific didactic competence.

\section{Introduction}

Over the past thirty years, a new profession (a translation teacher) has emerged. The realization of this fact did not come to translators immediately, but only after the training of translators became widespread and, accordingly, a large number of teachers needed to conduct such training. During the Soviet period, there was no targeted training of translation teachers. V.N. Komissarov wrote, "Translation is a discipline where the teacher's personality is a decisive factor in achieving the goal of learning" [1:340]. Citing Peter Newmark, Natasha Pavlović and Goranka Antunović claimed that the success of any translation course should depend $65 \%$ on the personality of the teacher, $20 \%$ on the course design and $15 \%$ on

\footnotetext{
* Corresponding author: artist232@rambler.ru
} 
the course materials [2: 1]. Over time, scattered studies concerned with teaching translation began to form a separate direction in translation studies, called "translation didactics". Within the framework of translation didactics, more attention was paid to the training of translation teachers, as indicated by Chakib Bnini [3: 1].

Despite an obvious theoretical interest in training translation teachers, this issue has not been solved. V.N. Komissarov's words are still true: “...currently, we do not have scientifically grounded programs for the training of translation teachers and are often required to teach translation blindly, by trial and error" [1:340]. Two decades passed, but the situation in the education system remains the same: "Unfortunately, more and more language faculties are struggling to survive, creating translation departments, using full-time teachers, whose basic qualifications are not in demand, so students study according to the old methods and approaches. Translation is taught by teachers of foreign languages or literature who have little or no experience in professional translation" [4: 98]. This state of affairs does not improve the quality of training professional translators. A translation teacher should have a special set of competences that ensure the fulfillment of their main mission, i.e. to form the professional translation thinking of students.

The article aims at analyzing the competences of a translation teacher and systematizing them. To attain this end, we need to solve the following tasks: consider various approaches to defining the competences of a translation teacher, analyze the existing models of a translation teacher's competences, create a unified model of a translation teacher's competences.

\section{Methods}

The main research method was a review of works determining the competences of a translation teacher over the past five-ten years. The scientific works under consideration present the study conducted by the most authoritative scholars in the field of translation didactics. In addition, we used the questionnaire method to create a generalized "image" of a translation teacher in relation to the Russian education system.

\section{Results}

A survey of 118 translation teachers from different Russian universities has confirmed our assumption that not all of them have an academic degree in translation: only $51.8 \%$ of the respondents are translators "by diploma"; the rest are philologists, teachers of foreign languages, teachers of Russian as a foreign language, specialists in the field of intercultural communication, etc. However, it is indicative that most respondents (76\%), both with the diploma in translation and without it, completed advanced training courses to become translation teachers; some of them $(9.1 \%)$ completed the professional retraining program "Translation teacher". Consequently, refresher courses and professional retraining programs remain the main method of theoretical and practical training of translation teachers. However, short-term courses do not allow students to form a comprehensive and systematic understanding of translation activities and tasks solved by a translator in real life. Moreover, they are often based on outdated provisions of the linguistic approach to translation theory.

There is reason to believe that the success of translation teachers is largely determined by their teaching experience. In this regard, we have obtained quite promising results: $78.5 \%$ of the respondents have teaching experience of 10 to 30 years, or more; $19 \%$ of the respondents have been teaching translation for more than 30 years.

It seems that the overall situation is not too bad. However, the important question is not how long teachers have been teaching translation, but how they did it. Without special 
training in the field of translation didactics, translation teachers most often copy their own teachers. It is good if they were taught by literate people. O.V. Petrov and A.V. Ivanov mentioned the same method of "self-learning" [5: 1077].

We can hope that translation educators can gain insight into the translation profession through their own translation experience. All the respondents stated that they had similar experience, and $58.7 \%$ had it for more than 10 years. However, our optimism decreases if we take into account that $81 \%$ of the respondents are engaged in practical translation for no more than 20 hours a month $(45.5 \%$ - less than 10 hours a month, $35.5 \%$ - from 10 to 20 hours a month) and only $19 \%$ of the respondents translate more than 20 hours a month. In other words, lecturers teaching translation studies are only occasionally involved in practical translation activities.

Thus, the survey conducted give grounds to assert that a modern translation teacher lacks: 1) basic theoretical training in the field of translation didactics and pedagogy, the knowledge of translation teaching methods; 2) practical translation experience and, as a result, a clear understanding of the translation profession, the specifics of the translation services market. Under these conditions, a translation teacher can hardly find professional happiness, i.e. feel self-confidence and self-efficacy (in English) [6] or autoeficacia (in Spanish) [7].

\section{Discussion}

Thus, a question arises: what competences should a translation teacher have to be happy?

Scholars are unanimous that a general requirement for a translation teacher is translation experience. Roberto Mayoral asserted quite categorically, "It is difficult to imagine how one can teach translation without professional experience" [8: 5]. Daniel Gouadec also agreed with the previous scholar [9: 13]. He distinguished between the same two categories of teachers: professional translators and teachers with translation experience [10]. In relation to the training of translators, this ability is formulated as "the ability to solve the tasks posed to students at a professional level" [2: 8]. However, sole translation skills are not enough to become a good translation teacher. The second mandatory quality is the ability to teach, i.e. to develop the necessary competences in students. This need is highlighted by many scholars who reviewed various competence models that are necessary for translation teachers [11]. The ability to translate includes several components and different authors determine different components of this skill $[2,12: 151,13]$. Perhaps the largest number of requirements for the preparation of a translation teacher (more than thirty) are presented by the EMT project participants [13]. It is worth mentioning that it is almost impossible to master so many competences independently, even if someone has a talent for teaching, which confirms our statement about the need for the systematic training of translation teachers.

A component of the systematic training of translation teachers should be the study of translation theory. This competence is mandatory for translation teachers [12: 151] for the following reason: while mastering the theory of translation, a student or teacher thereby learns a certain approach to translation in general and the solution of translation problems in particular, as well as reveals the essence of translation activity. Another thing is that this idea may be false and distorted or corresponding to the realities of the translation profession. Translation theory is characterized by a variety of conflicting approaches and concepts. Suffice to say that there is the opposition of a purely linguistic approach to translation based on the search for equivalence between texts and their segments, and the communicativefunctional approach, involving immersion in the communicative situation in which translation is made [14:298]. It is the communicative-functional approach to translation that should serve as a theoretical basis for the formation of professional translation thinking among translation teachers. 
It follows from the above that the acquisition of certain competences by translation teachers is inextricably linked with their knowledge of the translation market in all its diversity, new trends and phenomena that emerge in the translation profession. At the same time, teachers need to master those information technologies, whose use has become practically mandatory for any competent translator. Some scholars believe that information technology has become such an important tool for translating that it has a strong impact not only on the translation process, but also on the professional thinking of translators. This leads to the emergence of new paradigms in translation studies and their collision [15: 888]. These facts emphasize the extent to which knowledge about the translation profession and provisions of the theory of translation should be integrated into the mind of a translation teacher.

The foregoing allowed D.N. Shlepnev to develop a certain competence model of a translation teacher [16: 1232-1235]. In short, it includes three main blocks: professional translation competences; general and special didactic competences. General didactic competences should be inherent in the teacher, regardless of the subject being taught. Special didactic competences are associated with the teaching of actual translation disciplines. Translation competences and special didactic competences are divided into general and specific. Specific competences imply the ability to carry out certain types of translation activities and, accordingly, teach certain translation disciplines. Probably, the knowledge of translation theory should be attributed to general translation competences, and the knowledge of information technology belongs to specific translation competences.

\section{Conclusion}

Thus, the general competence model of a translation teacher should include the following blocks: professional translation competences; general didactic competences; special didactic competences (general - the mastery of translation didactics; special - the ability to teach specific translation disciplines).

Indeed, each of these blocks needs further specification.

\section{Acknowledgments}

The study was supported by the Russian Foundation for Basic Research within the framework of scientific project No. 20-013-00149.

\section{References}

1. V.N. Komissarov, Sovremennoe perevodovedenie [Modern translation studies] (Publishing House "ETS", Moscow, 2001)

2. N. Pavlović, G. Antunović, inTRAlinea, Special Issue: New Insights into Translator Training (2019) Accessed on: December 10, 2020. [Online]. Available: https://www.intralinea.org/index.php/specials/article/2423

3. C. Bnini, Didactics of Translation: Text in Context (Cambridge Scholars Publishing, Cambridge, 2016)

4. D.B. Koroleva, Filologicheskie Nauki. Voprosy Teorii i Praktiki, 9(51(1)), 96-99 (2015)

5. O. Petrova, A. Ivanov, EpSBS 86, 1075-1084 (2020).

https://doi.org/10.15405/epsbs.2020.08.125 
6. M. Haro-Soler, Current Trends in Translation Teaching and Learning English, 4, 198228 (2017)

7. E. Vizcaino Escobar Annia, K. López Morales, O. Klimenko, Katharsis, 25, 75-93 (2017)

8. R. Mayoral, Notes on Translator-Training (replies to a questionnaire), in A. Pym, C. Fallada, J. Ramón Biau, J. Orenstein (eds.), Innovation \& E-Learning in Translator Training, 3-10 (Universita Rovira i Virgili, Tarragon, 2003)

9. D. Gouadec, Notes on translator-training (replies to a questionnaire), in A. Pym, C. Fallada, J. Ramón Biau, J. Orenstein (eds.), Innovation \& E-Learning in Translator Training, 12-19 (Universita Rovira i Virgili, Tarragon, 2003)

10. Y. Zou, Advances in Social Science, Education and Humanities Research, 23, 786-793 (2015). https://doi.org/10.2991/icadce-15.2015.191

11. G. Massey, D. Kiraly, M. Ehrensberger-Dow, The Interpreter and Translator Trainer, 13(3), 211-215 (2019)

12. D. Kelly, A Handbook for Translator Trainers: A Guide to Reflective Practice (St. Jerome, Manchester, 2005)

13. The EMT Translator Trainer Profile. Competences of the Trainer of Translation (2013). Accessed on: December 20, 2020. [Online]. Available:

http://docplayer.net/14445272-The-emt-translator-trainer-profile-competences-of-thetrainer-in-translation.html

14. V.V. Sdobnikov, Russian Journal of Linguistics, 23(2), 295-327 (2019). https://doi.org/10.22363/2312-9182-2019-23-2-295-327.

15. Y. Gambier, International Journal of Communication, 10, 887-906 (2016)

16. V.V. Sdobnikov, R.M. Shamilov, D.N. Shlepnev, European Publisher, 86, 1227-1236 (2020) https://doi.org/10.15405/epsbs.2020.08.141 